\title{
Higher Education During the Pandemic: The Experience of Ukraine and Uzbekistan
}

\author{
Bezzubko Larysaํㅜ, Bezzubko Boris ${ }^{1}$, Eshniyazov Rustam ${ }^{2 *}$, Kamalov Janabay², Naurizbaev Aliakbar ${ }^{2}$, \\ Iskenderov Bakhtiyar ${ }^{2}$, Abatov Jalgas ${ }^{2}$ and Khojamuratov Kural ${ }^{2}$ \\ ${ }^{1}$ Donbass National Academy of Architecture and Civil Engineering, Ukraine \\ ${ }^{2}$ Karakalpak State University, Uzbekistan
}

\begin{abstract}
The coronavirus pandemic is having a very big impact on higher education. Higher education is forced to revise the forms of classes and introduce distance learning. The object of research in this article is the process of introducing distance education in higher education institutions as a result of the spread of the coronavirus pandemic. The subject of the study was the advantages and threats in the development of distance education. The article highlights the characteristic features of distance learning: distance learning occurs remotely using information and communication technologies in individual or collective form in synchronous (asynchronous) mode; interactively. Mandatory requirements for the organization of distance learning are considered. The article describes the problems that arise in higher education institutions when introducing distance learning: economic, technical, and social. In the course of the SWOT analysis of distance learning in higher education institutions, the strengths and weaknesses, threats and opportunities of this process are highlighted. Proposals have been developed to solve the problems that arise in higher education institutions in connection with the introduction of distance learning: the development of programs at the University and national level for the development of distance learning, methodological and technical support for this process, and the organization of training teachers in modern teaching methods.
\end{abstract}

KEYWORDS: E-learning; Educational Technology; Educational Research; Higher Education

\section{INTRODUCTION}

The coronavirus pandemic has had a major impact on all areas of human life: social, economic, and environmental issues. Many areas of life faced a serious challenge: it was urgent to solve the question of how to function under quarantine restrictions. In order to continue performing its functions, higher education is forced to revise the forms of conducting classes, shift the emphasis to the introduction of distance learning. The coronavirus pandemic continues, less than a year has passed since the introduction of quarantine restrictions. It is too early to sum up and draw conclusions on the following issues: "What impact did the coronavirus pandemic have on the quality of higher education?", "what changes in the higher education system were effective during the coronavirus pandemic?", " what are the directions for further development of higher education in view of the coronavirus pandemic?". But now there are scientific publications in which experts in the field of higher education try to analyze the experience of higher education institutions during the pandemic.

The first articles have appeared in a number of authoritative scientific journals devoted to higher education, and special issues on this topic are being prepared. Among the most interesting scientific papers on this topic are the following. The international Association of universities (IAU) published a report on the impact of COVID-19 "The impact of COVID-19 on higher education around the world in global survey report" [1]. It received 576 replies from 424 universities and other Higher Education Institutions (HEIs) based in 109 countries and two Special Administrative Regions of China (Hong Kong and Macao) As a result of processing the questionnaires, conclusions were drawn: the coronavirus significantly affected

Quick Response Code:

Address for correspondence: Eshniyazov Rustam, Karakalpak State University, Uzbekistan

Received: May 11, $2021 \quad$ Published: May 28, 2021

How to cite this article: Bezzubko L, Eshniyazov R, Kamalov J, Abatov J, Khojamuratov K. Higher Education During the Pandemic: The Experience of Ukraine and Uzbekistan. 2021- 3(3) OAJBS. ID.000287. DOI: $10.38125 /$ OAJBS.000287 
the success of higher education institutions; distance learning allows you to study in higher education institutions. The report also talks about the problems that have appeared as a result of the introduction of distance learning - distance learning can negatively affect the quality of training; there may be an increase in inequality among students as a result of different opportunities to receive this type of training ("increase inequality of learning opportunities"). These problems are especially evident in countries in Africa and Asia, where there is a low percentage of students using modern information technology and computer technology. Obviously, there are significant differences in the consequences, the degree of influence of the coronavirus on higher education, and possible directions for the development of higher education, depending on the country of study.

Giorgio [2] is devoted to the problems of learning during the pandemic. The article by Marinoni [3] draws the following conclusions: Despite these challenges, HEIs have reacted positively, often implementing new solutions to continue providing teaching, research, and service to society. There are articles that discuss the specific experience of switching to distance learning in individual higher education institutions [4-6]. Among the articles that consider the advantages and disadvantages of distance learning, we should mention the work of Mayra et al. [7], which notes as an advantage for the Institute - an increase in the number of visitors; and for the student - flexibility in the learning process.

Jesús et al. [8] prepared an overview of trends in the development of remote obroazovaniya based on the analysis of 248 articles. The authors considered problems in education in the direction of 3 aspects: (a) online students; (b) online teachers; and (c) an interactive learning environment. It is necessary to conduct further research on the quality of students ' education in the context of distance learning. A new working paper published by the National Bureau of Economic Research finds that students performed substantially worse, on average, on standardized course assessments at the end of the COVID-19 spring semester than in previous academic term [9]. The reviewed publications confirm the relevance of this issue in the scientific community, the presence of controversial issues [5]. This determines the object, subject of research, goals and objectives of the article. The object of research of this article is the process of introduction of distance education in higher education institutions as a result of the spread of the coronavirus pandemic. The subject of the study was the advantages and threats in the development of distance education. The main objectives of the article were to clarify the main characteristics of the object of research - " distance education in higher education institutions; analysis of the strengths and weaknesses, threats and advantages of implementing distance education; development of proposals for solving problems that arise in higher education institutions in connection with the introduction of distance learning during the coronavirus pandemic.

Methods. The main research methods used are: abstractlogical method for describing the theory of distance learning in higher education institutions; system analysis - for analyzing the organization of distance learning in higher education institutions , developing proposals for improving the use of distance learning in higher education institutions. The material for the article was collected as a result of generalizing the experience of two higher educational institutions-the Donbass national Academy of construction and architecture (Ukraine) and Karakalpak state University (Uzbekistan) [4,6].

\section{RESULTS AND DISCUSSION}

Distance learning is considered worldwide as one of the most effective means of continuing education during the pandemic, which ensures the continuity of the learning process. Higher education institutions around the world are faced with the challenge of introducing distance learning or continuing education using traditional methods, while exposing students and teachers to the risk of coronavirus infection, while creating an opportunity for the virus to spread. In most countries of the world, higher education institutions decided to switch to distance learning during the peak of the pandemic. However, many countries were almost not ready either methodically or technically to organize classes using distance learning. It was assumed that during the summer holidays and holidays in 2020, it is necessary to prepare for the introduction of distance learning in the 2020-2021 academic year. However, in such a short period of time, many problems of distance learning were not solved.

It should be noted that distance learning is not a completely new type of learning that is unknown to teachers. So, in Ukraine, back in 2013, Regulations on distance learning were issued [10], approved by the order of the Ministry of education of Ukraine. It described the legal and regulatory aspects of distance learning. The characteristics of distance learning during the pandemic include the following:

a) An individualized process of acquiring knowledge, skills and abilities occurs individually (student-teacher), collectively (a group of students and teachers);

b) Educational activities are carried out remotely using information and communication technologies;

c) Interactive interaction between teachers and students is carried out;

d) A certain amount of independent work of teachers and students with the materials of the information network is expected;

e) Distance learning can be conducted in synchronous mode (the subjects of training are simultaneously in the web environment) or asynchronous mode (the subjects of training interact with each other with a time delay).

The main requirements for the organization of distance learning are::

a) Students and teachers - computer and communication equipment, sufficient knowledge and skills to work with them in the process of distance learning.

b) Methodological support of disciplines prepared for distance learning.

c) Web environment of distance learning - a systemically organized set of web resources of academic disciplines (programs), software for managing web resources, means of interaction between subjects of distance learning, management and control of distance learning at the Institute.

In the course of the study, based on observations, surveys of students and teachers, the following groups of problems have been identified for subjects of distance learning:

1. Economic problems that arise in higher education institutions due to non-receipt of the planned amounts: 
a) The number of students enrolled in full-time education for the 1st year has Decreased, many students are transferred to distance learning, and the number of foreign students has significantly decreased due to the introduction of quarantine restrictions. And according to Australian universities, they expect to lose between $\$ 2$ billion and $\$ 3$ billion as a result of non-availability of tuition fees from international students [11].

b) Institutions should review existing agreements concluded with University students for tuition fees in the case of switching to distance learning.

c) There is a need to review the payment for accommodation in dormitories, if students go home as a result of switching to distance learning. In Ukraine, it was decided to refund the payment for a hostel for full-time students if students go home during distance learning.

d) There may be a reduction in wages of teachers in connection with distance learning. Although surveys have shown that the number of working hours for teachers has increased due to the need to prepare classes in distance learning, check students ' test papers, etc. e) There may be problems related to intellectual property due to the use of copyrighted courses that teachers are forced to post on the Internet.

2. Technical problems are associated with different levels of information technology use in higher education institutions in different countries. A relatively small number of universities before the pandemic introduced various elements of distance learning and used the Internet to post courses.

3. Social problems with teachers and students associated with the introduction of distance learning. We can talk about a certain psychological syndrome of "distance learning", which is accompanied by certain psychological emotional experiences, the absence (decrease) of social and emotional contacts among students and teachers, the emergence of social isolation, and a decrease in motivation to learn.

4. Teachers during distance learning have new functions related to the organization, coordination and control of distance learning. To implement new functions, it is necessary to develop the competence of teachers through training in appropriate courses. In the course of the study, a SWOT analysis of the organization of distance learning was made (Table 1 ).

Table 1: SWOT analysis of the organization of distance learning in higher education institutions.

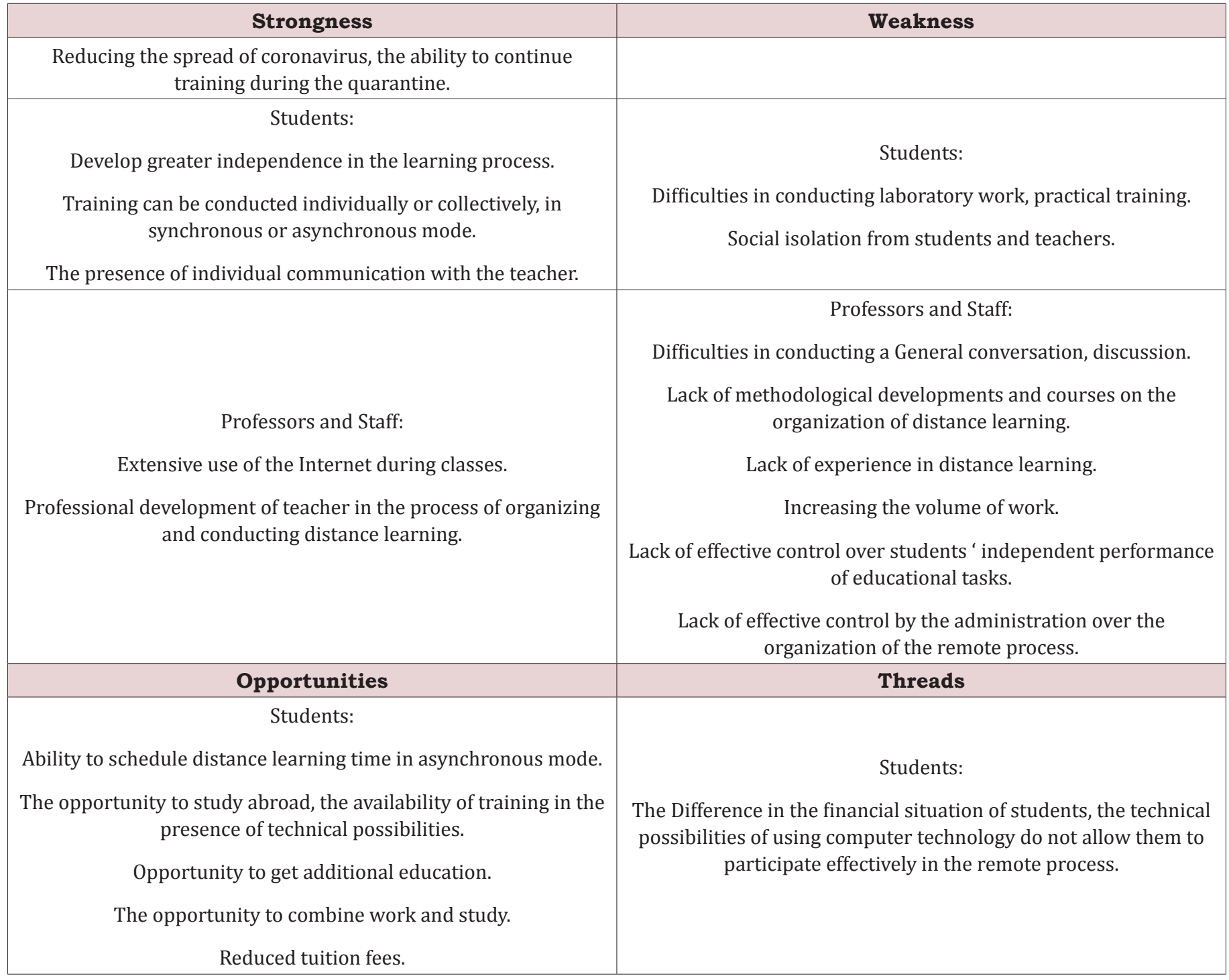




\begin{tabular}{|c|c|}
\hline Professors and Staff: & Professors and Staff: \\
\hline $\begin{array}{c}\text { Professional development of teachers, including computer } \\
\text { literacy. }\end{array}$ & $\begin{array}{c}\text { High competition between national education systems and foreign } \\
\text { ones may lead to an outflow of students from national higher } \\
\text { education institutions. }\end{array}$ \\
$\begin{array}{c}\text { High competition between national education systems and foreign } \\
\text { ones may lead to an outflow of students from national higher } \\
\text { education institutions. }\end{array}$ & $\begin{array}{c}\text { Reduction of funding for national higher education. } \\
\text { Reduction of funding for national higher education. }\end{array}$ \\
\hline
\end{tabular}

Source: Compiled by the authors based on the results of the study.

Despite the fact that, at first glance, the "weaknesses" and "threats" of teachers have become more as a result of the transition to distance learning, the analysis shows that the problems can be solved as a result of comprehensive systematic work on the introduction of distance education. Suggestions for solving the problems that arise in higher education institutions in connection with the introduction of distance learning during the coronavirus pandemic are as follows:

1. The need to solve technical problems requires the modernization of universities in order to increase their material and technical base, Informatization and digitalization.

2. Development of special programs and plans for the development of distance learning in higher educational institutions both at the local level (higher education institutions), national level (development of national programmes) and international level (programmes of international assistance in overcoming technical, technological backwardness higher education institutions in different countries).

3. Introduction of distance learning involves the development of technical, methodological and organizational support to create conditions for effective work; training teachers and students in modern teaching methods.

\section{CONCLUSION}

Distance learning during the coronavirus pandemic is a necessary measure. The article clarifies the concept of distance education and highlights its characteristic features. As a result of the analysis, the strengths and weaknesses, threats and advantages of implementing distance education for teachers and students of institutes were identified. It is Determined that the urgent task is to increase the effectiveness of distance learning, to create opportunities for its application in higher education institutions in different countries. For this purpose, proposals have been developed to address the problems that arise in higher education institutions in connection with the introduction of distance learning. The introduction of distance learning involves the implementation of technical, methodological and organizational training of teachers and students. To this end, it is necessary to develop programs and plans at the local (University), national and international levels for the development of distance learning, the development of methodological and technical, organizational support for this process, and the organization of training of teachers and students in modern teaching methods.

\section{REFERENCES}

1. Marinoni G, Hilligje L, Trine J (2020) The impact of COVID-19 on higher education around the world. IAU Global Impact Survey. pp. 1-50.

2. Giorgio M, Hilligje L (2020) The boston college center for international higher education. International higher education 102: 7-10.

3. Marinoni G, Hilligje L (2020) The Impact of COVID-19 on global higher education. International Higher Education 102: 7-9.

4. Alimov A, Bezzubko L, Abatov J, Khojamuratov K (2020) Integration, Partnership and Innovation in Construction Science and Education. MATEC Web of Conferences.

5. Tae ES, Song L (2020) College students' experience of emergency remote teaching due to COVID-19. Child Youth Serv Rev. 119: 105578.

6. Eshniyazov R (2020) Problemi obrazovaniya v usloviyah pandemii COVID-19. Nukus. pp. 200-203.

7. Mayra MSO, Antonio STP, Vinícius SP (2018) Distance education: advantages and disadvantages of the point of view of education and society. 29: 139-152.

8. Valverde-Berrocoso J, Garrido-Arroyo MC, Burgos-Videla C, MoralesCevallos MB (2020) Trends in educational research about e-Learning: A systematic literature review (2009-2018). Sustainability 12(12): 1-23.

9. George O, Douglas M, James B, Austin B, Thomas D, et al. (2020) Learning during the COVID-19 pandemic: it is not who you teach, but how you teach. NBER Working Papers 28022. National Bureau of Economic Research.

10. Polojenniya (2013) pro distantsiyna navchanniya: zatv. Nakazom Ministerstva osviti Ukraini. p. 466.

11. Witze A (2020) Universities will never be the same after the coronavirus crisis. Nature 582(7811): 162-164. 